\title{
Efektivitas model pembelajaran Relating, Experiencing, Applying, Cooperating, Transferring (REACT) dan reciprocal teaching berbantuan game edukasi
}

\author{
Niswatun Hasanah ${ }^{1}$, Achmad Buchori ${ }^{1 *}$ (D), Dina Prasetyowati ${ }^{1}$, Farida Nursyahidah ${ }^{1}$ \\ ${ }^{1}$ Program Studi Pendidikan Matematika, Universitas PGRI Semarang, Indonesia \\ *Corresponding Author. E-mail: achmadbuchori@upgris.ac.id
}

\begin{tabular}{ll}
\hline \multicolumn{1}{c}{ ARTICLE INFO } & \multicolumn{1}{c}{ ABSTRACT } \\
\hline Article History: & Penelitian ini bertujuan untuk mendeskripsikan efektivitas model pembelajaran Relating, Expe- \\
Received: 04 Dec. 2017 & riencing, Applying, Cooperating, Transferring (REACT) berbantuan Game Edukasi dan Recipro- \\
Revised: 16 April 2019 & cal Teaching berbantuan Game Edukasi ditinjau dari kemampuan pemecahan masalah mate- \\
Accepted: 28 June 2019 & matis siswa. Penelitian ini adalah quasi experiment dengan posttest only control design. Popu- \\
& lasi dalam penelitian ini adalah siswa kelas VIII MTs Sultan Fatah Gaji Demak tahun ajaran \\
& 2017/2018 dan kelas VIII-A, VIII-B, dan VIII-C dipilih sebagai sampel penelitian. Hasil penelitian \\
Keywords: & menunjukkan bahwa (1) terdapat perbedaan signifikan rata-rata kemampuan pemecahan \\
pemecahan masalah & masalah matematis antara siswa yang mendapatkan pembelajaran dengan model REACT \\
matematis & berbantuan Game Edukasi, model Reciprocal Teaching berbantuan Game Edukasi, dan model \\
Mathematical problem- & pembelajaran konvensional (ekspositori); (2) kemampuan pemecahan masalah matematis \\
solving & siswa yang belajar menggunakan model pembelajaran REACT berbantuan Game Edukasi lebih \\
REACT & baik dari pada siswa yang belajar dengan pembelajaran konvensional; (3) kemampuan peme- \\
Reciprocal teaching & cahan masalah matematis siswa yang belajar menggunakan model Reciprocal Teaching ber- \\
Game edukasi & bantuan Game Edukasi lebih baik dari pada siswa yang belajar dengan pembelajaran konven- \\
& sional; (4) pembelajaran dengan model REACT dan Reciprocal Teaching berbantuan Game \\
& Edukasi sama-sama efektif ditinjau dari kemampuan pemecahan masalah dengan rata-rata \\
& kemampuannya signifikan di atas 70; dan (5) terdapat pengaruh positif keaktifan siswa pada \\
& kelas yang belajar menggunakan model REACT dan Reciprocal Teaching berbantuan Game \\
& Education terhadap kemampuan pemecahan masalah matematis siswa.
\end{tabular}

This research aimed to describe the effectiveness of Relating, Experiencing, Applying, Cooperating, Transferring (REACT) learning models assisted by Educational Game and Reciprocal Teaching assisted by Educational Game in terms of students' mathematical problem-solving abilities. This study was a quasi-experiment with a posttest only control design. The population in this research was students of 8th-grade of MTs Sultan Fatah Gaji Demak, Indonesia in the academic year 2017/2018 and class VIII-A, VIII-B, and VIII-C were selected as research samples. The results showed that (1) there was a significant difference in the average mathematical problem-solving ability between students who received learning with the REACT model assisted by Educational Game, the Reciprocal Teaching model assisted by Educational Games, and conventional learning models (expository); (2) the mathematical problem-solving ability of students who learn using REACT learning models assisted by Educational Games was better than conventional learning; (3) the mathematical problem-solving ability of students who learn using the Reciprocal Teaching model assisted by Educational Game was better than conventional learning; (4)The learning with the REACT and Reciprocal Teaching models assisted by Educational Games was equally effective in terms of problem solving skills with an average ability significantly above 70; and (5) there was a positive correlation between the activeness of students in class learning using REACT and Reciprocal Teaching models assisted by Game Education on students' mathematical problem-solving abilities.

SCAN ME

This is an open access article under the CC-BY-SA license (c) (i) (2)

\section{How to Cite:}

Hasanah, N., Buchori, A., Prasetyowati, D., \& Nursyahidah, F. (2019). Efektivitas model pembelajaran Relating, Experiencing, Applying, Cooperating, Transferring (REACT) dan reciprocal teaching berbantuan game edukasi. PYTHAGORAS: Jurnal Pendidikan Matematika, 14(1), 92-101. doi: https://doi.org/10.21831/pg.v14i1.17157 


\section{PENDAHULUAN}

Pendidikan adalah suatu proses enkulturasi, berfungsi mewariskan dan mengembangkan nilai-nilai budaya dan prestasi masa lalu menjadi nilai-nilai budaya dan karakter bangsa yang sesuai dengan kehidupan masa kini dan masa datang. Pendidikan juga merupakan usaha suatu masyarakat dan bangsa dalam mempersiapkan generasinya untuk menghadapi tantangan demi keberlangsungan hidup di masa depan. Menurut Yuniawatika (2011) dalam menghadapi tantangan era globalisasi saat ini diperlukan sumber daya manusia yang handal yang memiliki pemikiran kritis, sistematis, logis, kreatif, dan kemauan kerjasama yang efektif. Sumber daya manusia yang memiliki pemikiran seperti yang telah disebutkan tentunya dihasilkan melalui proses pendidikan yang diselenggarakan oleh lembaga pendidikan atau sekolah. Salah satu mata pelajaran di sekolah yang dapat digunakan untuk mencapai tujuan tersebut adalah matematika, karena matematika memiliki keterkaitan dengan kehidupan sehari-hari baik masa kini maupun masa mendatang.

National Council of Teachers of Mathematics [NCTM] (2000) menyatakan bahwa standar matematika sekolah haruslah meliputi standar isi dan standar proses. Standar proses meliputi pemecahan masalah, penalaran dan pembuktian, keterkaitan, komunikasi, dan representasi (NCTM, 2000). Tujuan pembelajaran matematika diantaranya adalah memecahkan masalah yang meliputi kemampuan memahami masalah, merancang model matematika, menyelesaikan model matematika, menafsirkan solusi yang diperoleh. Oleh karena itu, kemampuan pemecahan masalah menjadi fokus pembelajaran matematika di semua jenjang pendidikan terutama di jenjang SMP dan SMA.

Kemampuan pemecahan masalah ini erat kaitannya dengan komponen pemahaman siswa dalam bermatematika. Polya (1973) menyatakan bahwa tahapan pertama dalam memecahkan masalah matematika adalah memahami masalah matematika itu sendiri. Kaitan antara kemampuan pemahaman dengan pemecahan masalah dapat dipertegas bahwa, jika seseorang telah memiliki kemampuan pemahaman terhadap konsep-konsep matematika, maka ia mampu menggunakannya untuk memecahkan masalah. Sebaliknya, jika seseorang dapat memecahkan suatu masalah, maka orang tersebut harus memiliki kemampuan pemahaman terhadap konsep-konsep matematika yang telah dipelajari sebelumnya.

Faktor-faktor yang menyebabkan ketidakmampuan siswa memecahkan masalah matematika banyak, yang paling dominan adalah cara mengajar guru (Anggraini, Siroj, \& Putri, 2010). Guru-guru masih mengajar dengan cara lama, dimana guru ataupun peneliti menyampaikan materi dengan metode ceramah, kemudian siswa mencatat materi dan mengerjakan soal-soal rutin. Terbiasanya siswa mengerjakan soal-soal rutin membuat siswa tidak dapat memecahkan suatu masalah apabila diberikan soal-soal yang berbentuk nonrutin. Mereka tidak terbiasa untuk memecahkan suatu masalah secara bebas dan mencari solusi penyelesaiannya dengan cara mereka sendiri. Mereka hanya bisa mengerjakan soal-soal yang bentuknya sama dengan contoh soal yang diberikan guru. Apabila soalnya berbeda mereka mulai kebingungan karena mereka tidak memahami langkah-langkah dalam memecahkan suatu masalah.

Dari observasi di salah satu MTs di Demak, diperoleh informasi bahwa siswa masih mengalami kesulitan dalam memecahkan permasalahan matematika. Banyak siswa yang tidak menerapkan langkah-langkah pemecahan masalah yang tepat. Dalam proses pembelajaran, siswa juga kurang didorong untuk mengembangkan kemampuan memecahkan masalah. Hasil ulangan harian pada materi operasi aljabar pada kelas VIII tahun ajaran 2016/2017 di salah satu MTs yang diobservasi, menunjukkan bahwa hanya 40,60\% siswa yang dinyatakan tuntas dengan nilai KKM untuk mata pelajaran matematika adalah 70. Selain itu, hasil wawancara dengan salah satu siswa pada MTs tersebut, diperoleh informasi bahwa mata pelajaran matematika adalah mata pelajaran yang sulit dipahami. Penggunaan media pembelajaran juga jarang dilakukan oleh guru. Media pembelajaran yang digunakan hanya berupa Lembar Kegiatan Siswa (LKS), papan tulis, spidol, dan tidak ada variasi model pembelajaran, sehingga siswa cepat bosan dengan proses pembelajaran yang monoton. Hasil wawancara dengan guru mata pelajaran matematika pada MTs tersebut menunjukkan bahwa siswa cenderung pasif dalam pembelajaran. Siswa hanya terpaku pada contoh soal dengan tipe yang sama, seperti yang diberikan oleh guru. Begitu juga ketika diberikan penugasan, kebanyakan siswa hanya menyalin punya teman, namun ketika diberikan soal dengan tipe yang berbeda dari contoh soal yang diberikan, siswa tidak bisa mengerjakan. Siswa juga hanya menerima informasi dan menghafalnya, sehingga kurang memahami informasi-informasi yang diterimanya. Kesulitan yang dialami siswa antara lain siswa tidak mampu menerjemahkan soal cerita, siswa tidak tahu apa saja yang diketahui dan ditanyakan, dan tidak mampu mengubah soal cerita dalam model matematikanya. Ada juga siswa yang telah dapat 
mengindentifikasi apa saja yang diketahui dan ditanyakan dalam soal cerita, tetapi tidak tahu bagaimana urutan mengerjakannya, karena siswa tidak mampu menghubungkan soal dengan teori yang ada.

Apa yang telah dikemukakan sebelumnya menunjukkan bahwa rendahnya peran aktif dan kemampuan pemecahan masalah matematis siswa dalam pembelajaran matematika. Guru juga kurang memberikan inovasi, sehingga proses pembelajaran menjadi kurang menarik dan kurang bermakna bagi siswa. Untuk mengatasi berbagai kendala tersebut, diperlukan suatu model pembelajaran inovatif yang dapat meningkatkan peran aktif sekaligus kemampuan pemecahan masalah matematis siswa. Salah satu model pembelajaran yang dapat menangani permasalahan tersebut adalah model pembelajaran REACT dan Reciprocal Teaching.

Menurut Fauziah (2010) metode, pendekatan, atau strategi seperti apa yang dapat melatih kemampuan siswa dalam memecahkan masalah adalah metode, pendekatan, atau strategi yang melibatkan aktivitas siswa secara optimal, dan membuat pembelajaran matematika menjadi lebih bermakna dan menyenangkan. Salah satu bentuk pembelajaran alternatif yang dirancang sedemikian rupa sehingga mencerminkan keterlibatan siswa secara aktif adalah melalui strategi REACT yang merupakan singkatan dari Relating, Experiencing, Applying, Cooperating, Transferring. Model pembelajaran REACT menekankan pada pemberian informasi yang berkaitan dengan informasi yang sebelumnya telah diketahuai oleh siswa, sehingga siswa akan lebih mudah memahami konsep-konsep yang disampaikan oleh guru, karena sering dijumpai dalam kehidupan sehari-hari (Putri, Mardiyana, \& Saputro, 2019; Fakhruriza \& Kartika, 2015). Penerapan model pembelajaran REACT diharapkan dapat memberikan nuansa baru dalam proses pembelajaran. Berdasarkan penelitian Rohati (2011) diperoleh hasil bahwa rata-rata setiap kelompok aktif mengikuti proses pembelajaran yang dikembangkan dengan dengan strategi REACT. Hal ini juga didukung dengan penelitian (Yuniawatika, 2011) yang menunjukkan bahwa pembelajaran dengan strategi REACT dibandingkan dengan pembelajaran biasa menunjukkan pangaruh yang signifikan terhadap peningkatan kemampuan pemecahan masalah matematis siswa.

Selain REACT, model pembelajaran yang diduga dapat digunakan untuk meningkatkan kemampuan pemecahan masalah siswa yaitu Reciprocal Teaching. Model pembelajaran Reciprocal Teaching (pembelajaran terbalik) pertama kali dikembangkan oleh Anne Marrie Palinscar dan Anne Brown pada tahun 1984 (Rachmayani, 2014). Reciprocal Teaching adalah suatu pendekatan pembelajaran yang menerapkan empat strategi pemahaman mandiri, yaitu menyimpulkan bahan ajar, menyusun pertanyaan dan menyelesaikannya, menjelaskan kembali pengetahuan yang telah diperolehnya, kemudian memprediksikan pertanyaan selanjutnya dari persoalan yang disodorkan kepada siswa. Haryati dan Fauziyah (2009) menambahkan bahwa pembelajaran terbalik merupakan pembelajaran dengan memilih seorang siswa agar berperan seperti guru untuk menjelaskan materi yang belum disampaikan guru kepada siswa lainnya. Pembelajaran terbalik dapat diterapkan kepada siswa melalui empat strategi pemahaman mandiri yang spesifik, yaitu merangkum atau meringkas, membuat pertanyaan, mampu menjelaskan, dan dapat memprediksi.

Berdasarkan penelitian Haryati dan Fauziyah (2009) ditemukan bahwa implementasi metode pembelajaran terbalik (Reciprocal Teaching) dapat meningkatkan kemampuan pemecahan masalah siswa. Selain itu, hasil penelitian Argikas dan Khuzaini (2016) menunjukkan bahwa pembelajaran dengan model Reciprocal Teaching juga dapat meningkatkan pemahaman konsep matematika siswa. Hasil-hasil penelitian tersebut menunjukkan dampak positif dari model pembelajaran Reciprocal Teaching dalam meningkatkan pemahaman konsep matematika dan meningkatkan kemampuan pemecahan masalah siswa. Hal tersebut disebabkan karena model pembelajaran Reciprocal Teaching dalam proses pembelajarannya berpusat pada siswa, sehingga siswa termotivasi untuk belajar dan memahami materi-materi yang ada dalam matematika. Dengan termotivasinya siswa maka diharapkan dapat mengoptimalkan aktivitas belajar siswa.

Untuk memperoleh aktivitas dan hasil belajar yang optimal, maka pembelajaran perlu didukung oleh media pembelajaran yang relevan (Ayda \& Widjajanti, 2014; Fahmi \& Marsigit, 2014; Hidayati, Widjajanti, Susanti, Arliani, \& Subekti, 2012). Salah satu media pembelajaran yang dapat digunakan yaitu game edukatif. Wibisono dan Yulianto (2010) mengemukakan bahwa game sebagai media pembelajaran adalah sutu permainan yang dapat menghibur yang bertujuan untuk bisa menjadi alat pembelajaran. Game untuk media pembelajaran ini dirancang untuk memberi pertanyaan bagi pengguna dan memberi pilihan jawaban yang ada. Penggunaan game dalam pembelajaran merupakan bagian dari integrasi teknologi sebagai sarana pembelajaran. Teknologi merupakan alat yang ampuh untuk mengembangkan kualitas pembelajaran. Dengan menggunakan teknologi dalam bentuk media pembelajaran yang tepat, siswa akan lebih mudah memahami pembelajaran dan guru juga akan terbantu dengan 
adanya media tersebut. Dalam perkembangannya, pemanfaatan game di bidang pendidikan mengalami perkembangan yang signifikan. Menurut Novaliendry (2013) dalam pemanfaatannya media pembelajaran game edukasi sangat penting untuk menunjang pembelajaran. Berdasarkan hasil penelitian yang telah dilakukan oleh Sudargo, Buchori, dan Rahmawati (2015) bahwa media pembelajaran berupa game edukasi efektif digunakan melalui smartphone dan komputer. Dengan demikian, game edukasi dalam pembelajaran matematika dapat diintegrasikan melalui pemanfaatan smartphone maupun komputer.

Berdasarkan latar belakang masalah dan kajian-kajian teoritis yang telah dikemukakan sebelumnya, maka dapat dipahami bahwa penggunaan media pembelajaran inovatif seperti REACT dan Reciprocal Teaching yang diintegrasikan dengan pemanfaatan game edukasi diduga kuat dapat meningkatkan kemampuan pemecahan masalah matematis siswa. Dengan demikian, tujuan dari penelitian ini adalah untuk mendeskripsikan efektivitas model pembelajaran REACT dan Reciprocal Teaching berbantuan Game Edukasi ditinjau dari kemampuan pemecahan masalah matematis siswa.

\section{METODE}

Penelitian ini dilakukan di MTs Sultan Fatah Gaji Demak, Jawa Timur. Penelitian ini dilakukan dengan tujuan untuk mengatasi permasalahan yang ada berkenaan dengan kemampuan pemecahan masalah matematis siswa, terutama dalam mata pelajaran matematika. Desain penelitian yang digunakan adalah posttest only control design, seperti disajikan pada Tabel 1.

Tabel 1. Desain Eksperimen

\begin{tabular}{lcc}
\hline Kelompok & Perlakuan & Posttest \\
\hline Eksperimen I $\left(\mathrm{E}_{1}\right)$ & $\mathrm{X}_{1}$ & $\mathrm{O}_{1}$ \\
Eksperimen II $\left(\mathrm{E}_{2}\right)$ & $\mathrm{X}_{2}$ & $\mathrm{O}_{2}$ \\
Kontrol $(\mathrm{K})$ & $\mathrm{X}_{3}$ & $\mathrm{O}_{3}$ \\
\hline
\end{tabular}

Keterangan:

$\mathrm{X}_{1}$ : Pembelajaran dengan model REACT berbantuan Game Edukasi

$\mathrm{X}_{2}$ : Pembelajaran dengan model Reciprocal Teaching berbantuan Game Edukasi

$\mathrm{X}_{3}$ :Pembelajaran ekspositori (konvensional)

$\mathrm{O}_{1}$ : Posttest kemampuan pemecahan masalah kelompok eksperimen 1

$\mathrm{O}_{2}$ :Posttest kemampuan pemecahan masalah kelompok eksperimen 2

$\mathrm{O}_{3}$ : Posttest kemampuan pemecahan masalah kelompok kontrol

Populasi dalam penelitian ini adalah semua siswa kelas VIII dan IX MTs Sultan Fatah Gaji Demak tahun pelajaran 2017/2018. Pengambilan sampel menggunakan teknik sampling purposive yaitu teknik penentuan sampel dengan pertimbangan tertentu. Dengan menggunakan teknik sampling purposive berdasarkan pertimbangan guru yang mengajar di kelas VIII diperoleh 3 kelas sebagai sampel penelitian, yaitu kelas VIII-A sebagai kelas eksperimen 1, kelas VIII-B sebagai kelas eksperimen 2, dan kelas VIII-C sebagai kelas kontrol. Selanjutnya diambil kelas IXB sebagai kelas uji coba.

Variabel penelitian adalah segala sesuatu yang berbentuk apa saja yang ditetapkan peneliti untuk dipelajari sehingga diperoleh informasi tentang hal tersebut, kemudian ditarik kesimpulannya (Sugiyono, 2015). Variabel dalam penelitian ini dibedakan menjadi dua yaitu variabel bebas dan variabel terikat. Variabel bebas dalam penelitian ini adalah model pembelajaran yang diterapkan, yaitu pembelajaran REACT berbantuan Game Edukasi, pembelajaran Reciprocal Teaching berbantuan Game Edukasi, dan pembelajaran ekspositori. Variabel terikat dalam penelitian ini adalah kemampuan pemecahan masalah matematis siswa.

Teknik pengumpulan data yang digunakan adalah observasi dan tes. Observasi digunakan untuk memperoleh data keaktifan siswa pada kelas eksperimen dan kelas kontrol selama mengikuti pembelajaran. Instrumen observasi berupa lembar pengamatan keaktifan siswa yang diisi oleh pengamat. Tes digunakan untuk mengukur pencapaian kemampuan pemecahan masalah matematis siswa pada materi operasi aljabar dalam bentuk soal uraian. Pemberian skor untuk kemampuan pemecahan masalah matematika pada tes uraian yang dimodifikasi dari rubrik Cai, Lane, dan Jakabesin (1996) yaitu seperti disajikan pada Tabel 2. 
Tabel 2. Rubrik Pemberian Skor Tes Kemampuan Pemecahan Masalah

\begin{tabular}{llc}
\hline Indikator Pemecahan Masalah Matematika & Jawaban & Skor \\
\hline $\begin{array}{l}\text { Mengidentifikasi, data diketahui, data } \\
\text { ditanyakan, kecukupan data untuk }\end{array}$ & $\begin{array}{l}\text { Mengidentifikasi data diketahui, ditanyakan, dan } \\
\text { pemecahan masalah }\end{array}$ & $\begin{array}{l}\text { kecukupan data/unsur serta melengkapinya bila } \\
\text { diperlukan dan menyatakannya dalam simbol } \\
\text { matematika yang relevan }\end{array}$ \\
$\begin{array}{l}\text { Mengidentifikasi strategi yang dapat } \\
\text { digunakan }\end{array}$ & $\begin{array}{l}\text { Mengidentifikasi beberapa strategi yang dapat } \\
\text { digunakan untuk menyelesaikan model matematika } \\
\text { yang bersangkutan }\end{array}$ & $0-3$ \\
Menyelesaikan model matematika disertai & $\begin{array}{l}\text { Menetapkan/memilih strategi yang paling relevan } \\
\text { dan menyelesaikan model matematika berdasarkan }\end{array}$ & $0-4$ \\
Memeriksa kebenaran solusi yang & gambar dan ekspresi matematika yang telah disusun \\
diperoleh & Memeriksa kebenaran solusi ke masalah asal & $0-2$ \\
\hline \multicolumn{2}{c}{ Skor satu butir tes pemecahan masalah matematika } \\
\hline
\end{tabular}

Hipotesis yang akan diuji dalam penelitian ini yaitu: (1) terdapat perbedaan signifikan rata-rata kemampuan pemecahan masalah siswa antara kelompok eksperimen 1 (REACT + Game Edukasi), kelompok eksperimen 2 (Reciprocal Teaching + Game Edukasi), dan kelompok kontrol; (2) terdapat perbedaan signifikan rata-rata kemampuan pemecahan masalah antara kelompok eksperimen 1 dan kelompok kontrol; (3) terdapat peredaan signifikan rata-rata kemampuan pemecahan masalah siswa kelompok eksperimen 2 dan kelompok kontrol; (4) pembelajaran dengan model REACT dan Reciprocal Teaching berbantuan Game Edukasi efektif ditinjau dari kemampuan pemecahan masalah; (5) terdapat korelasi positif keaktifan siswa pada kelompok eksperimen terhadap kemampuan pemecahan masalah siswa.

Analisis data dilakukan menggunakan statistik inferensial. Hipotesis 1 dianalisis menggunakan uji ANOVA, hipotesis 2 dan hipotesis 3 dianalisis menggunakan independent sample t-test, hipotesis 4 dianalisis menggunakan one sample t-test dengan kriteria keefektifan yang ditetapkan yaitu 70, sedangkan hipotesis 5 dianalisis menggunakan uji regresi sederhana. Sebelum uji hipotesis dilakukan, terlebih dahulu akan dilakukan uji prasyarat yang bertujuan untuk membuktikan apakah data pada masing-masing kelompok perlakuan berdistribusi normal (uji normalitas data) dan berasal dari populasi yang homogen (uji kesamaan varians). Semua analisis statistik dalam penelitian ini dilakukan pada taraf signifikan $5 \%(\alpha=0,05)$.

\section{HASIL DAN PEMBAHASAN}

Data yang diperoleh dalam penelitian ini yaitu data kemampuan pemecahan masalah matematis siswa yang bersumber dari tiga kelompok perlakuan, yaitu kelompok eksperimen 1 (REACT + Game Edukasi), kelompok eksperimen 2 (Reciprocal Teaching + Game Edukasi), dan kelompok kontrol (ekspositori). Sebelum melakukan pengujian hipotesis, beberapa uji prasyarat dilakukan, yaitu uji normalitas dan homogenitas data. Uji normalitas data bertujuan untuk membuktikan apakah data yang diperoleh dari ketiga kelompok perlakuan berdistribusi normal. Adapun hasil pengujian normalitas data tersebut disajikan pada Tabel 3.

Tabel 3. Hasil Uji Normalitas Data

\begin{tabular}{lcccc}
\hline Kelompok & $N$ & $L_{O}$ & $L_{\text {tabel }}$ & Kesimpulan \\
\hline Kontrol & 26 & 0,1329 & 0,1690 & Normal \\
Eksperimen 1 & 29 & 0,1154 & 0,1610 & Normal \\
Eksperimen 2 & 28 & 0,1093 & 0,1630 & Normal \\
\hline
\end{tabular}

Hasil analisis pada Tabel 3 menunjukkan bahwa nilai $L_{O}<L_{\text {tabel }}$ untuk ketiga kelompok perlakuan, sehingga tidak cukup bukti untuk menolak $\mathrm{H}_{0}$. Dengan demikian dapat disimpulkan bahwa data yang berasal dari kelompok eksperimen 1, eksperimen 2, dan kontrol memiliki distribusi normal.

Selanjutnya, untuk mengetahui apakah ketiga kelompok yang menjadi sampel mempunyai varians yang homogen atau tidak, maka perlu dilakukan uji homogenitas. Adapun hasil pengujian terhadap kesamaan varians ketiga kelompok perlakuan disajikan pada Tabel 4. 
PYTHAGORAS: Jurnal Pendidikan Matematika, 14 (1), 2019 - 97

Niswatun Hasanah, Achmad Buchori, Dina Prasetyowati, Farida Nursyahidah

Tabel 4. Hasil Uji Homogenitas

\begin{tabular}{lcccccc}
\hline Kelompok & $n_{i}$ & $d k\left(n_{i}-1\right)$ & $S_{i}^{2}$ & $\left(n_{i}-1\right) \times S_{i}^{2}$ & $\log S_{i}^{2}$ & $\left(n_{i}-1\right) \times \log S_{i}^{2}$ \\
\hline Eksperimen 1 & 29 & 28 & 73,194 & 2049,432 & 1,8645 & 52,205 \\
Eksperimen 2 & 28 & 27 & 43,146 & 1164,942 & 1,6349 & 44,143 \\
Kontrol & 26 & 25 & 46,941 & 1173,525 & 1,6716 & 41,789 \\
Jumlah & 83 & 80 & 163,281 & 4387,899 & 5,1710 & 138,138 \\
\hline & & & & & $\chi_{\text {hitung }}^{2}$ & 2,293 \\
& & & & & $\chi_{\text {tabel }}^{2}$ & 5,99 \\
\hline
\end{tabular}

Tabel 4 menunjukkan bahwa nilai $\chi^{2}{ }_{\text {hitung }}<\chi^{2}{ }_{\text {tabel }}$, sehingga tidak cukup bukti untuk menolak $\mathrm{H}_{0}$. Dengan demikian dapat disimpulkan bahwa varians dari ketiga kelompok perlakuan adalah sama, sehingga asumsi homogenitas terpenuhi.

Untuk mengetahui kesamaan rata-rata kemampuan pemecahan masalah sebelum diberi perlakuan antara kelompok kontrol, kelompok eksperimen 1, dan kelompok eksperimen 2, dilakukan uji kesamaan rata-rata dengan uji ANOVA. Dari hasil perhitungan diperoleh $F=1,953$. Pada taraf signifikan $5 \%$, derajat bebas pembilang 2 , dan derajat bebas penyebut 80 , diperoleh $F_{\text {tabel }}=3,44$. Hasil tersebut menunjukkan bahwa $F<F_{\text {tabel, }}$, sehingga tidak cukup bukti untuk menolak $\mathrm{H}_{0}$. Dengan demikian dapat disimpulkan bahwa tidak terdapat perbedaan signifikan rata-rata nilai kemampuan pemecahan masalah matematis siswa pada ketiga kelompok sebelum diberi perlakuan.

Selanjutnya uji untuk mengetahui kesamaan rata-rata kemampuan pemecahan masalah setelah diberi perlakuan antara kelompok kontrol, kelompok eksperimen 1, dan kelompok eksperimen 2 (hipotesis 1), juga dilakukan uji kesamaan rata-rata dengan uji ANOVA. Dari hasil perhitungan diperoleh $F=6,823$. Pada taraf signifikan $5 \%$, derajat bebas pembilang 2 , dan derajat bebas penyebut 80 , diperoleh $F_{\text {tabel }}=3,44$. Hasil tersebut menunjukkan bahwa $F>F_{\text {tabel, }}$ sehingga cukup bukti untuk menolak $H_{0}$. Dengan demikian dapat disimpulkan bahwa terdapat perbedaan signifikan rata-rata nilai kemampuan pemecahan masalah matematis siswa pada ketiga kelompok sebelum diberi perlakuan.

Hipotesis 2 yaitu membandingkan rata-rata kemampuan pemecahan masalah kelompok yang mendapat perlakuan dengan menggunakan model pembelajaran REACT berbantuan Game Edukasi dengan kelompok yang mendapat perlakuan dengan model pembelajaran ekspositori, diuji menggunakan uji Scheeffe. Dari hasil perhitungan diperoleh $f=11,535$ dan $f_{\text {tabel }}=4,024$. Hasil perhitungan tersebut menunjukkan bahwa $f>f_{\text {tabel, }}$, sehingga cukup bukti untuk menolak $\mathrm{H}_{0}$. Dengan demikian dapat disimpulkan bahwa terdapat perbedaan signifikan rata-rata kemampuan pemecahan masalah matematis antara kelompok yang mendapatkan pembelajaran REACT berbantuan Game Edukasi dan kelompok yang belajar menggunakan pembelajaran ekspositori.

Selanjutnya pengujian terhadap hipotesis 3 , yaitu membandingkan rata-rata kemampuan pemecahan masalah kelompok yang mendapat perlakuan dengan menggunakan model pembelajaran Reciprocal Teaching berbantuan Game Edukasi dengan kelompok yang mendapat perlakuan dengan model pembelajaran ekspositori, juga diuji menggunakan uji Scheeffe. Dari hasil perhitungan diperoleh $f=12,159$ dan $f_{\text {tabel }}=4,024$. Hasil perhitungan tersebut menunjukkan bahwa $f>f_{\text {tabel, }}$, sehingga cukup bukti untuk menolak $\mathrm{H}_{0}$. Dengan demikian dapat disimpulkan bahwa terdapat perbedaan signifikan rata-rata kemampuan pemecahan masalah matematis antara kelompok yang mendapatkan pembelajaran Reciprocal Teaching berbantuan Game Edukasi dan kelompok yang belajar menggunakan pembelajaran ekspositori.

Hipotesis 4 diuji dengan one sample t-test yang bertujuan untuk membuktikan apakah perlakuan pada kelompok eksperimen 1 dan eksperimen 2 efektif ditinjau dari nilai kemampuan pemecahan masalah yang telah dihipotesiskan. Secara statistik, hipotesis yang akan diuji yaitu $\mathrm{H}_{0}: \mu=70$ vs. $\mathrm{H}_{1}: \mu>70$. Pada kelompok eksperimen 1 , diperoleh nilai $t=10,162$, derajat bebas $(d k)=28, \alpha=0,05$, sehingga nilai $t_{\text {tabel }}=1,701$. Berdasarkan hasil perhitungan tersebut terlihat bahwa nilai $t>t_{\text {tabel, }}$, sehingga cukup bukti untuk menolak $\mathrm{H}_{0}$. Dengan demikian, dapat disimpulkan bahwa perlakuan pada kelompok eksperimen 1 yaitu berupa pembelajaran dengan model REACT berbantuan Game Edukasi efektif ditinjau dari kemampuan pemecahan masalah matematis siswa dengan nilai rata-ratanya signifikan mencapai lebih dari 70. Pada kelompok eksperimen 2, diperoleh nilai $t=8,236$, derajat bebas $(d k)=27, \alpha$ $=0,05$, sehingga nilai $t_{\text {tabel }}=1,703$. Berdasarkan hasil perhitungan tersebut terlihat bahwa nilai $t>t_{\text {tabee, }}$ sehingga cukup bukti untuk menolak $\mathrm{H}_{0}$. Dengan demikian, dapat disimpulkan bahwa perlakuan pada kelompok eksperimen 
2 yaitu berupa pembelajaran dengan model Reciprocal Teaching berbantuan Game Edukasi efektif ditinjau dari kemampuan pemecahan masalah matematis siswa dengan nilai rata-ratanya signifikan mencapai lebih dari 70.

Pengujian terhadap hipotesis 5 menggunakan uji regresi yang bertujuan untuk menentukan model statistik (dalam bentuk formula matematika) yang dipakai untuk memprediksi nilai-nilai variabel terikat yaitu kemampuan pemecahan masalah $(Y)$ berdasarkan nilai-nilai dari variabel bebas yaitu keaktifan siswa $(X)$. Berdasarkan perhitungan diperoleh persamaan regresi pada kelas eksperimen 1 yaitu $\widehat{Y}=41,0082+0,44866 X$. Begitu pula untuk kelas eksperimen 2 persamaan regresinya yaitu $\hat{Y}=43,1487+0,43411 X$. Uji $F$ dilakukan untuk menguji keberartian model regresi linear sederhana pada kelompok eksperimen 1 dan kelompok eksperimen 2. Pada kelompok eksperimen 1 diperoleh $F=4,253$, dengan $\alpha=0,05, d k_{1}=1$, dan $d k_{2}=29$ diperoleh nilai $F_{\text {tabel }}=4,21$. Karena $F>F_{\text {tabel, }}$ maka dapat disimpulkan bahwa $\mathrm{H}_{0}$ ditolak. Hal ini berarti bahwa hubungan linear antara keaktifan siswa dalam pembelajaran dengan kemampuan pemecahan masalahnya pada kelompok eksperimen 1 berarti. Pada kelompok eksperimen 2 diperoleh $F=6,682$, dengan $\alpha=0,05, d k_{1}=1$, dan $d k_{2}=28$ diperoleh nilai $F_{\text {tabel }}=4,20$. Karena $F>F_{\text {tabel, }}$ maka dapat disimpulkan bahwa $\mathrm{H}_{0}$ ditolak. $\mathrm{Hal}$ ini berarti bahwa hubungan linear antara keaktifan siswa dalam pembelajaran dengan kemampuan pemecahan masalahnya pada kelompok eksperimen 2 juga berarti.

Uji keberartian koefisien regresi linear sederhana kelas eksperimen 1 dengan $\alpha=0,025$ dan $d k=28$, maka nilai $t_{\text {tabel }}=1,701$. Untuk koefisien $b=0,21754$ didapatkan $t=2,062$. Berdasarkan hasil tersebut maka $\mathrm{H}_{0}$ ditolak, sehingga dapat disimpulkan bahwa koefisien $\beta$ berarti. Artinya ada pengaruh signifikan antara keaktifan terhadap kemampuan pemecahan masalah matematis pada kelompok eksperimen 1 , dan karena $b=0,217$ bernilai positif, maka terdapat pengaruh positif antara keaktifan terhadap kemampuan pemecahan masalah matematis pada kelompok eksperimen 1 . Selanjutnya, uji keberartian koefisien regresi linear sederhana kelas eksperimen 2 dengan $\alpha=0,025$ dan $d k=27$, maka nilai $t_{\text {tabel }}=1,703$. Untuk koefisien $b=0,16794$ didapatkan $t=2,58493$. Berdasarkan hasil tersebut maka $\mathrm{H}_{0}$, sehingga dapat disimpulkan bahwa koefisien $\beta$ berarti. Artinya ada pengaruh signifikan antara keaktifan terhadap kemampuan pemecahan masalah matematis pada kelompok eksperimen 2, dan karena $b=0,168$ bernilai positif, maka terdapat pengaruh positif antara keaktifan terhadap kemampuan pemecahan masalah matematis pada kelompok eksperimen 2.

Koefisien determinasi pada kelas eksperimen 1 yaitu $r^{2}=0,14$. Hal tersebut menunjukkan bahwa $14 \%$ kemampuan pemecahan masalah matematis siswa pada kelompok eksperimen 1 dipengaruhi oleh keaktifan, sisanya ditentukan oleh faktor lain. Selanjutnya, koefisien determinasi pada kelas eksperimen 2 yaitu $r^{2}=0,20$. Hal tersebut menunjukkan bahwa 20\% kemampuan pemecahan masalah matematis siswa pada kelompok eksperimen 2 ditentukan oleh keaktifan, sisanya ditentukan oleh faktor lain.

\section{Pembahasan}

Hasil penelitian secara umum menunjukkan bahwa kedua perlakuan yang diberikan yaitu pembelajaran menggunakan model REACT berbantuan Game Edukasi dan pembelajaran menggunakan model Reciprocal Teaching berbantuan Game Edukasi memberikan dampak positif bagi kemampuan pemecahan masalah matematis siswa. Hasil penelitian ini tentunya dapat dijadikan sebagai bukti empiris bahwa kedua model dan media pembelajaran yang digunakan dalam penelitian ini direkomendasikan untuk diterapkan dalam pembelajaran matematika, terutama untuk meningkatkan kemampuan pemecahan masalah. Selain itu, implementasi kedua perlakuan tersebut dalam pembelajaran matematika juga terbukti meningkatkan partisipasi aktif siswa selama pembelajaran berlangsung, dimana partisipasi aktif tersebut juga berpengaruh signifikan terhadap kemampuan pemecahan masalah matematis siswa. Dengan demikian, hasil penelitian ini dapat memberikan kontribusi teoritis maupun praktik bagi perbaikan proses pembelajaran matematika saat ini dan di masa yang akan datang.

Hasil penelitian menunjukkan bahwa pembelajaran menggunakan model REACT berbantuan Game Edukasi terbukti efektif ditinjau dari kemampuan pemecahan masalah matematis siswa. Temuan ini tentunya sejalan dengan temuan penelitian-penelitian sebelumnya (misalnya: Chizary \& Farhangi, 2017; Marlissa \& Widjajanti, 2015; Putri et al.,2019; Putri \& Santosa, 2015). Terdapat beberapa hal yang menyebabkan efektifnya model REACT berbantuan Game Edukasi dalam meningkatkan kemampuan pemecahan masalah matematis siswa. Pertama, model REACT berbantuan Game Edukasi menuntut siswa untuk berperan aktif untuk mengkonstruk pengetahuannya. Selain itu, dengan dipadukan dengan Game Edukasi menjadikan pembelajaran lebih menarik dan menyenangkan (Chizary \& Farhangi, 2017; Wijaya, 2009). Adanya perpaduan antara pembelajaran menarik dan menyenangkan serta keterlibatan aktif siswa dalam pembelajaran berdampak positif terhadap motivasi belajar siswa, termasuk dalam menyelesaikan masalah-masalah matematika. Kedua, model REACT berbantuan Game Edukasi mampu 
membuat siswa lebih mudah dalam memahami konsep yang dipelajari, karena siswa dilibatkan langsung dalam membangun pengetahuan serta adanya latihan yang disajikan dalam bentuk game menjadikan siswa lebih antusias untuk memahami setiap materi yang dipelajari. Wijaya (2009) mengemukakan bahwa bermain game yang berkaitan dengan materi yang sedang dipelajari dapat meningkatkan kemampuan siswa untuk memahami materi pelajaran yang kompleks. Dengan demikian, baik model REACT maupun Game Edukasi sama-sama memiliki kontribusi terhadap peningkatan pemahaman konsep siswa.

Hasil penelitian juga menunjukkan bahwa pembelajaran menggunakan model Reciprocal Teaching berbantuan Game Edukasi juga efektif ditinjau dari kemampuan pemecahan masalah matematis siswa. Temuan penelitian tersebut memperkuat temuan-temuan penelitian sebelumnya (misalnya: Afdhal \& Sugiman, 2017; Andira, Santoso, \& Yusup, 2018; Chen \& Kong, 2017; Meyer, 2014). Menurut Meyer (2014) Reciprocal Teaching efektif untuk diterapkan dalam kelompok pemecahan masalah matematika. Dengan adanya kelompok tersebut memungkinkan siswa untuk berkolaborasi dan bertukar pikiran, sehingga memudahkan bagi siswa untuk memahami dan menyelesaikan masalah matematika. Chen dan Kong (2017) telah merekomendasikan bahwa penggunaan multimedia efektif mengembangkan potensi Reciprocal Teaching. Dengan demikian, adanya perpaduan antara model Reciprocal Teaching dengan media pembelajaran berupa Game Edukasi diduga kuat menjadi salah satu penyebab meningkatnya kemampuan siswa dalam menyelesaikan masalah matematika.

Pembelajaran yang baik tidah hanya semata fokus mengembangkan kemampuan berpikir siswa, tetapi hendaknya juga diorientasikan pada pengembangan karakter siswa (Zurqoni, Retnawati, Apino, \& Anazifa, 2018; Zurqoni, Retnawati, Arlinwibowo, \& Apino, 2018). Salah satu kunci dalam pengembangan karakter yaitu melalui pembiasaan terhadap hal-hal positif, seperti interaksi sosial selama proses pembelajaran berlangsung. Interaksi social tersebut dapat difasilitasi melalui kegiatan diskusi kelompok maupun diskusi kelas. Model pembelajaran REACT dan Reciprocal Teaching sangat memungkinkan ketika dalam pelaksanaannya siswa diajak untuk berdiskusi baik secara kelompok maupun diskusi kelas (Chen \& Kong, 2017; Meyer, 2014). Dengan demikian, interaksi sosial yang tercipta melalui model pembelajaran REACT dan Reciprocal Teaching ikut berkontribusi terhadap perkembangan karakter siswa, sehingga model ini sangat relevan dengan kebutuhan pendidikan saat ini.

\section{SIMPULAN}

Berdasarkan hasil penelitian dan pembahasan, penelitian ini menghasilkan beberapa kesimpulan. Pertama, terdapat perbedaan signifikan rata-rata kemampuan pemecahan masalah matematis antara siswa yang mendapatkan pembelajaran dengan model REACT berbantuan Game Edukasi, model Reciprocal Teaching berbantuan Game Edukasi, dan model pembelajaran konvensional (ekspositori). Kedua, kemampuan pemecahan masalah matematis siswa yang belajar menggunakan model pembelajaran REACT berbantuan Game Edukasi lebih baik dari pada siswa yang belajar dengan pembelajaran konvensional. Ketiga, kemampuan pemecahan masalah matematis siswa yang belajar menggunakan model Reciprocal Teaching berbantuan Game Edukasi lebih baik dari pada siswa yang belajar dengan pembelajaran konvensional. Keempat, pembelajaran dengan model REACT dan Reciprocal Teaching berbantuan Game Edukasi sama-sama efektif ditinjau dari kemampuan pemecahan masalah dengan rata-rata kemampuannya signifikan di atas 70 . Kelima, terdapat pengaruh positif keaktifan siswa pada kelas yang belajar menggunakan model REACT dan Reciprocal Teaching berbantuan Game Edukasi terhadap kemampuan pemecahan masalah matematis siswa.

Berdasarkan simpulan penelitian, peneliti menyarankan beberapa hal. Pertama, guru matematika hendaknya mencoba untuk menggunakan berbagai model pembelajaran inovatif untuk melatihkan kemampuan pemecahan masalah matematis siswa. Model pembelajaran REACT dan Reciprocal Teaching sangat potensial diterapkan di kelas untuk mencapai tujuan tersebut, dan hasil penelitian ini dapat dijadikan sebagai jaminan bahwa kedua model tersebut dapat diterapkan secara efektif pada pembelajaran di kelas. Kedua, kebosanan sering kali menjadi permasalahan bagi siswa dalam proses pembelajaran matematika. Untukitu, pemanfaatan Game Edukasi dapat dijadikan sebagai alternatif untuk mengatasi hal tersebut. Ketika pemanfaatan Game Edukasi tersebut dipadukan dengan model REACT dan Reciprocal Teaching, terbukti dapat meningkatkan kemampuan pemecahan masalah matematis siswa. Dengan demikian, kreativitas guru dalam memadukan antara media dan model pembelajaran tersebut diperlukan untuk mencapai hasil belajar yang optimal. Ketiga, penelitian ini tentunya masih memiliki keterbatasan, untuk itu diharapkan agar kedepannya peneliti lain dapat melakukan penelitian serupa pada materi ataupun jen- 
jang kelas yang berbeda, serta dengan menggunakan populasi yang lebih luas. Hal tersebut tentunya memungkinkan generalisasi yang lebih luas terhadap hasil penelitian yang menggunakan model pembelajaran REACT, Reciprocal Teaching, serta pemanfaatan Game Edukasi sebagai media pembelajaran.

\section{DAFTAR PUSTAKA}

Afdhal, M., \& Sugiman, S. (2017). Pengembangan perangkat pembelajaran berbasis reciprocal teaching berorientasi pada antusiasme dan kemampuan berpikir kritis siswa. Pythagoras: Jurnal Pendidikan Matematika, 12(2), 173-186. doi: https://doi.org/10.21831/pg.v12i2.17716

Argikas, T., \& Khuzaini, N. (2016). The application of reciprocal teaching method for improving the understanding of mathematics concept of 7th grade students SMP Negeri 2 Depok. Jurnal Mercumatika: Jurnal Penelitian Matematika dan Pendidikan Matematika, 1(1). doi: http://dx.doi.org/10.26486/mercumatika.v1i1.186

Andira, T., Santoso, B., \& Yusup, M. (2018). Penerapan model pembelajaran reciprocal teaching ditinjau dari kemampuan penalaran matematis peserta didik pada materi bangun datar segi empat. Pythagoras: Jurnal Pendidikan Matematika, 13(1), 88-98. doi: https://doi.org/10.21831/pg.v13i1.16579

Anggraini, L., Siroj, R. A., \& Putri, R. I. I. (2013). Penerapan model pembelajaran investigasi kelompok untuk meningkatkan kemampuan pemecahan masalah matematika siswa kelas VIII-4 SMP Negeri 27 Palembang. Jurnal Pendidikan Matematika, 4(1), 33-44. doi: https://doi.org/10.22342/jpm.4.1.309

Ayda, E., \& Widjajanti, D. B. (2014). Pengembangan perangkat pembelajaran teorema Pythagoras dengan media berbantuan komputer. Jurnal Riset Pendidikan Matematika, 1(2), 216-226. doi: https://doi.org/10.21831/jrpm.v1i2.2677

Cai, J. , Jakabcsin, M. S., \& Lane, S. (1996), Assessing students' mathematical communication. School Science and Mathematics, 96(5), 238-246. doi: https://doi.org/10.1111/j.1949-8594.1996.tb10235.x

Chen, Y., \& Kong, D. (2017). An investigation on factors in the integration of reciprocal teaching into multimedia teaching. EURASIA Journal of Mathematics Science and Technology Education, 13(1), 133-142. doi: http://doi.org/10.12973/eurasia.2017.00608a

Chizary, F., \& Farhangi, A. (2017). Efficiency of educational games on mathematics learning of students at second grade of primary school. Journal of History Culture and Art Research, 6(1), 232-240. doi: http://dx.doi.org/10.7596/taksad.v6i1.738

Fahmi, S., \& Marsigit, M. (2014). Pengembangan multimedia macromedia flash dengan pendekatan kontekstual dan keefektifannya terhadap sikap siswa pada matematika. Pythagoras: Jurnal Pendidikan Matematika, 9(1), 90-98. doi: https://doi.org/10.21831/pg.v9i1.9071

Fakhruriza, O., \& Kartika, I. (2015). Keefektifan model pembelajaran Relating, Experience, Applying, Cooperating, Transferring (REACT) untuk meningkatkan hasil belajar siswa SMP pada materi kalor. Jurnal Riset dan Kajian Pendidikan Fisika, 2(2), 54-57. doi: http://dx.doi.org/10.12928/jrkpf.v2i2.3250

Fauziah, A. (2010). Peningkatan kemampuan pemahaman dan pemecahan masalah matematik siswa SMP melalui strategi REACT. Forum Kependidikan, 30(1), 1-13. Retrived from http://forumkependidikan.unsri.ac.id/ userfiles/ANA\%2OFAUZIAH.pdf

Haryati, J. T., \& Fauziyah, F. (2009). Implementasi metode pembelajaran berbalik (reciprocal teaching) pada mata pelajaran akuntansi. Dinamika Pendidikan, 4(2), 175-194. doi: https://doi.org/10.15294/dp.v4i2.354

Hidayati, K., Widjajanti, D. B., Susanti, M., Arliani, E., \& Subekti, R. (2012). Upaya menumbuhkan dan meningkatkan keterampilan mahasiswa Prodi Pendidikan Matematika FMIPA UNY dalam membuat media kartun untuk pembelajaran statistika dan peluang di SMP dan SMA. Pythagoras: Jurnal Pendidikan Matematika, 3(2), 5164. doi: https://doi.org/10.21831/pg.v3i2.677

Marlissa, I., \& Widjajanti, D. (2015). Pengaruh strategi REACT ditinjau dari gaya kognitif terhadap kemampuan pemecahan masalah, prestasi belajar dan apresiasi siswa terhadap matematika. Jurnal Riset Pendidikan Matematika, 2(2), 186 -196. doi: https://doi.org/10.21831/jrpm.v2i2.7333 
Meyer, K. (2014). Making meaning in mathematics problem-solving using the reciprocal teaching approach. Literacy Learning: the Middle Years, 22(2), 7-14. Retrieved from https://eprints.usq.edu.au/25401/7/ Meyer_LLMY_v22n2_PV.pdf

NCTM. (2000). Principles and standards for school mathematics. Reston, VA: Author.

Novaliendry, D. (2013). Aplikasi game geografi berbasis multimedia interaktif (studi kasus siswa kelas IX SMPN 1 RAO). Jurnal Teknologi Informasi \& Pendidikan, 6(2), 106-118.

Polya, G. (1973). How to solve it (2nd ed.) Princeton, NJ: Princeton University Press.

Putri, M. E., Mardiyana, M., \& Saputro, D. R. S. (2019). The effect of application of REACT learning strategies on mathematics learning achievements: Empirical analysis on learning styles of junior high school students. International Journal of Educational Research Review, 4(2), 231-237. doi: https://doi.org/10.24331/ijere.518065

Putri, R., \& Santosa, R. H. (2015). Keefektifan strategi REACT ditinjau dari prestasi belajar, kemampuan penyelesaian masalah, koneksi matematis, self-efficacy. Jurnal Riset Pendidikan Matematika, 2(2), 262-272. doi: https://doi.org/10.21831/jrpm.v2i2.7345

Rachmayani, D. (2014). Penerapan pembelajaran reciprocal teaching untuk meningkatkan kemampuan komunikasi matematis dan kemandirian belajar matematika siswa. Jurnal Pendidikan Unsika, 2(1), 13-23. Retrieved from https://journal.unsika.ac.id/index.php/judika/article/view/118/122

Rohati, R. (2011). Pengembangan bahan ajar materi bangun ruang dengan menggunakan strategi Relating, Experiencing, Applying, Cooperating, Transferring (REACT) di sekolah menengah pertama. Edumatica: Jurnal Pendidikan Matematika, 1(2), 61-73. Retrieved from https://online-journal.unja.ac.id/index.php/edumatica/ article/view/32

Sudargo, S., Buchori, A., \& Rahmawati, N. D. (2015). Desain pengembangan digital math game dengan model etnomatematika pada mata kuliah matematika SMA. Retrieved from http://eprints.upgris.ac.id/10/

Sugiyono, S. (2013). Metode penelitian dan kuantitatif, kualitatif, dan R\&D. Bandung: Alfabeta.

Wibisono, W., \& Yulianto, L. (2010). Perancangan game edukasi untuk media pembelajaran pada Sekolah Menengah Pertama Persatuan Guru Republik Indonesia Gondang Kecamatan Nawangan Kabupaten Pacitan. Journal Speed: Sentra Penelitian Engineering Dan Edukasi, 2(2), 37-42. doi: http://dx.doi.org/10.3112/speed.v2i2.878

Wijaya, A. (2009). The power of games to learn mathematics: An overview. Pythagoras: Jurnal Pendidikan Matematika, 5(1), 1-12. doi: https://doi.org/10.21831/pg.v5i1.552

Yuniawatika, (2011). Penerapan pembelajaran matematika dengan strategi REACT untuk meningkatkan kemampuan koneksi dan representasi matematik siswa sekolah dasar. Jurnal Pendidikan Matematika, Edisi Khusus (2),107-120. Retrieved from http://jurnal.upi.edu/file/12-Yuniawatika-EDIT.pdf

Zurqoni, Retnawati, H., Apino, E., \& Anazifa, R. D. (2018). Impact of character education implementation: A goal-free evaluation. Problems of Education in the 21st Century, 76(6), 881-899. doi: http://doi.org/10.33225/pec/18.76.881

Zurqoni, Retnawati, H., Arlinwibowo, J., \& Apino, E. (2018). Strategy and implementation of character education in senior high schools and vocational high schools. Journal of Social Studies Education Research, 9(3), 370-397. Retrieved from https://jsser.org/index.php/jsser/article/view/294 